\title{
Insulin secretion profiles are modified by overexpression of glutamate dehydrogenase in pancreatic islets
}

\author{
S. Carobbio ${ }^{1}$ H. Ishihara ${ }^{1}$ S. Fernandez-Pascual ${ }^{2}$ C. Bartley ${ }^{1} \cdot$ R. Martin-Del-Rio $^{3} \cdot$ P. Maechler ${ }^{1}$ \\ ${ }^{1}$ Division of Clinical Biochemistry, University Medical Center, Geneva, Switzerland \\ 2 Department of Biochemistry, Complutense University Medical School, Madrid, Spain \\ ${ }^{3}$ Department of Investigation, Hospital "Ramón y Cajal”, Madrid, Spain
}

\begin{abstract}
Aims/hypothesis. Glutamate dehydrogenase (GDH) is a mitochondrial enzyme playing a key role in the control of insulin secretion. However, it is not known whether GDH expression levels in beta cells are ratelimiting for the secretory response to glucose. GDH also controls glutamine and glutamate oxidative metabolism, which is only weak in islets if GDH is not allosterically activated by L-leucine or (+/-)-2-aminobicyclo-[2,2,1]heptane-2-carboxylic acid (BCH).

Methods. We constructed an adenovirus encoding for GDH to overexpress the enzyme in the beta-cell line INS-1E, as well as in isolated rat and mouse pancreatic islets. The secretory responses to glucose and glutamine were studied in static and perifusion experiments. Amino acid concentrations and metabolic parameters were measured in parallel.

Results. GDH overexpression in rat islets did not change insulin release at basal or intermediate glucose ( 2.8 and $8.3 \mathrm{mmol} / \mathrm{l}$ respectively), but potentiated the secretory response at high glucose concentrations
\end{abstract}

(16.7 mmol/l) compared to controls $(+35 \%)$. Control islets exposed to $5 \mathrm{mmol} / \mathrm{l}$ glutamine at basal glucose did not increase insulin release, unless $\mathrm{BCH}$ was added with a resulting 2.5 -fold response. In islets overexpressing GDH glutamine alone stimulated insulin secretion (2.7-fold), which was potentiated 2.2-fold by adding $\mathrm{BCH}$. The secretory responses evoked by glutamine under these conditions correlated with enhanced cellular metabolism.

Conclusions/interpretation. GDH could be rate-limiting in glucose-induced insulin secretion, as GDH overexpression enhanced secretory responses. Moreover, GDH overexpression made islets responsive to glutamine, indicating that under physiological conditions this enzyme acts as a gatekeeper to prevent amino acids from being inappropriate efficient secretagogues. [Diabetologia (2004) 47:266-276]

Keywords Insulin secretion - Glutamate dehydrogenase · Glutamine · BCH · GDH · Pancreatic islets $\cdot$ Beta cell
Received: 28 July 2003 / Revised: 27 October 2003

Published online: 20 December 2003

(C) Springer-Verlag 2003

P. Maechler $(\bullet)$

Division of Clinical Biochemistry, Room 9100,

University Medical Center, 1 rue Michel-Servet,

1211 Geneva 4, Switzerland

E-mail: pierre.maechler@medecine.unige.ch

Abbreviations: AUC, Area under the curve $\cdot \mathrm{BCH}$, (+/-)-2-aminobicyclo-[2,2,1]heptane-2-carboxylic acid $\cdot \Delta \Psi_{\mathrm{m}}$, mitochondrial membrane potential $\cdot$ FCCP, carbonyl cyanide p-trifluoromethoxyphenylhydrazone - GABA, $\gamma$-aminobutyric acid - GDH, glutamate dehydrogenase - HPLC, high-pressure liquid chromatography $\cdot \mathrm{KRBH}$, Krebs-Ringer bicarbonate HEPES buffer - MTT, 3-(4,5-dimethylthiazol-2-yl)-2,5,diphenyl tetrazolium bromide · RPMI, Roswell Park Memorial Institute $\cdot$ TCA, tricarboxylic acid
Glutamate dehydrogenase (GDH; EC 1.4.1.3), encoded by GLUD1 [1], is a homohexamer located in the mitochondrial matrix. GDH catalyses the reversible reaction $\alpha$-ketoglutarate $+\mathrm{NH}_{3}+\mathrm{NAD}(\mathrm{P}) \mathrm{H} \leftrightarrow$ glutamate $+\mathrm{NAD}(\mathrm{P})^{+}[2]$. In the brain, this enzyme ensures the cycling of the neurotransmitter glutamate to glutamine between neurons and astrocytes [3]. GDH also plays a major role in ammonia metabolism and detoxification, mainly in the liver and the kidney [4]. In the pancreatic beta cells, the importance of GDH as a key enzyme in the control of insulin secretion was recognised long ago [5]. Inhibition of its activity was shown to decrease insulin release [6] as well as glutamate concentrations [7]. Conversely, activating mutations of GDH have been associated with a hyperinsulinism syndrome $[8,9]$. The enzyme is allosterically regulat- 
ed by leucine, pyridine, adenine and guanine nucleotides [10, 11]. Reduced GTP-mediated inhibition of the enzyme was associated with most GDH mutations linked to the hyperinsulinism syndrome [12]. The importance of GDH, and the related glutamate pathway in general, is also highlighted by debate on the role of glutamate as an intracellular messenger in glucosestimulated insulin exocytosis $[13,14,15,16,17,18]$.

In pancreatic beta cells, the increase of cytosolic $\mathrm{Ca}^{2+}$ levels is necessary to elicit insulin exocytosis, although it does not account for the full effect of glucose [19]. Primarily, mitochondria fulfill the pivotal function of generating signals coupling glucose sensing to insulin secretion [20]. Mitochondrial metabolism generates ATP, which promotes the closure of ATP-sensitive $\mathrm{K}^{+}$channels [21] and, as a consequence, the depolarisation of the plasma membrane [22]. This leads to $\mathrm{Ca}^{2+}$ influx through voltage-gated $\mathrm{Ca}^{2+}$ channels and a rise in cytosolic $\mathrm{Ca}^{2+}$ triggering insulin exocytosis [23]. Then, additive signals are generated by glucose and contribute to the sustained phase of insulin release [19].

Unlike glucose, glutamine is not efficiently processed through oxidative metabolism in beta cells and, as a result, does not stimulate insulin release on its own $[24,25]$. Probably, only a small fraction of the total GDH flux is used under normal conditions [26], because of the important allosteric control of this enzyme. Indeed, glutamine oxidation can be prompted by allosteric activation of GDH, an effect correlating with stimulation of insulin secretion [25, 27]. However, glucose exposure inhibits glutamine oxidation [28] and glutamate formation from glutamine [29]. Therefore, GDH could play a dual role in glutamate handling [30]. On the one hand, this could be a cataplerotic role when glutamate is produced as a glucose-derived factor [31] implicated in the stimulation of insulin exocytosis. On the other hand, it could be an anaplerotic role when glutamate serves as a mitochondrial substrate feeding the tricarboxylic acid (TCA) cycle. Taken together, these modes of action point to GDH as a major regulatory enzyme for the control of insulin secretion.

Several studies have reported the effects of GDH allosteric regulation on insulin release $[32,33]$. In our study we investigated combined alterations of GDH expression with allosteric regulation of the enzyme. GDH was overexpressed in the beta cell line INS-1E, as well as in isolated pancreatic islets of rat and mouse origin. In these conditions, responses to glucose, the main insulin secretagogue, as well as to glutamine were tested.

\section{Materials and methods}

Cell culture. Adenovirus amplification was done in HEK-293 cells cultured in DMEM medium with $10 \%$ fetal calf serum.
The clonal beta cell line INS-1E [34], derived from parental INS-1 cells [35], was cultured in Roswell Park Memorial Institute (RPMI) 1640 medium with $5 \%$ fetal calf serum. Adherent cultured INS-1E cells were infected with recombinant adenovirus for $90 \mathrm{~min}$ at $37^{\circ} \mathrm{C}$, washed once, and further cultured in complete RPMI-1640 medium for 18 to $20 \mathrm{~h}$ before experiments.

Animals. Wistar rats or BALB/c mice weighing 200 to $250 \mathrm{~g}$ and 25 to $30 \mathrm{~g}$ respectively were obtained from in-house breeding (CMU-Zootechnie, Geneva, Switzerland). We followed the principles of laboratory animal care and the study was approved by the responsible ethics committee. Pancreatic islets were isolated by collagenase digestion from male Wistar rats or $\mathrm{BALB} / \mathrm{c}$ mice as described previously [36]. Isolated islets were cultured free-floating in RPMI-1640 medium for $24 \mathrm{~h}$ before adenovirus transduction.

Adenovirus construction. Recombinant adenovirus encoding human GLUD1 under the chicken actin promoter [37] was generated as described previously [15, 38]. The plasmid hGLUD1-pcDNA3 containing full-length human GLUD1 cDNA [8] was kindly provided by Dr C.A. Stanley and Dr B.Y. Hsu (The Children's Hospital of Philadelphia, Philadelphia, Pa., USA). Following Pst I digestion, the insert with blunt ends was sub-cloned in a cosmid pAdCAG [38], previously opened by $S w a I$. The presence and right orientation of the insert were checked by restriction enzyme digestions using ClaI and BglII (Invitrogen, La Jolla, Calif., USA). The cosmid containing $h G L U D 1$ (pAd-CAG-hGLUDl) and the adenovirus type 5 DNA terminal protein complex (DNA-TPC) were cotransfected using calcium phosphate (CellPhect, Amersham Pharmacia, Piscataway, N.J., USA) in HEK-293 cells, which were seeded in 96-well plates. Ten days after transfection the cell lysate was used to infect 24 -well plates, the adenoviral DNA was extracted from the cells and analysed by DNA digestion with ClaI and XhoI to check for the presence of $h G L U D 1$. The cell lysate containing the virus with full-length $h G L U D 1$ (AdCA-hGLUDl) was used to infect two $138-\mathrm{mm}$ dishes of HEK-293 cells. The virus was purified by $\mathrm{CsCl}$ ultracentrifugation (L8-70M, Beckman Coulter, Fullerton, Calif., USA) and referred to as Ad-GDH. AdCA-lacZ, which expresses bacterial $\beta$-galactosidase, was used as a control adenovirus (Ad-LacZ).

Transductions were done by infection of INS-1E cells or rodent islets with $1.0 \mu \mathrm{l}$ of purified virus per $\mathrm{ml}$ of media (unless otherwise stated) for $90 \mathrm{~min}$, corresponding to approximately 40 PFU/cell.

Immunoblotting, GDH activity, and immunofluorescence. SDSPAGEs were run using $5 \mu \mathrm{g}$ protein of INS-1E cell or islet extracts [39] per lane or standard of purified bovine GDH (Roche Diagnostics, Rotkreuz, Switzerland) on $11 \%$ gel. Proteins were transferred on to nitrocellulose membrane and incubated overnight at $4{ }^{\circ} \mathrm{C}$ in the presence of rabbit anti-GDH polyclonal antibody (1:5000) raised against bovine GDH (Rockland, Gilbertsville, Pa., USA). The membrane was then incubated for $1 \mathrm{~h}$ at room temperature with donkey anti-rabbit $\mathrm{IgG}$ antibody (1:5000) conjugated to horseradish peroxidase (ECL, Amersham, Zürich, Switzerland), and the GDH protein was revealed by chemiluminescence (Pierce, Rockford, Ill., USA).

GDH activity was measured from cell extracts of transduced INS-1E cells lysed in $20 \mathrm{mmol} / \mathrm{l}$ Tris- $\mathrm{HCl} \mathrm{pH} 8.0$, $2 \mathrm{mmol} / \mathrm{l}$ CDTA and $0.2 \%$ Tween-20. GDH activity was monitored under the oxidative deamination direction as NADH fluorescence excited at $340 \mathrm{~nm}$ and measured at $460 \mathrm{~nm}$ in $1.5 \mathrm{ml}$ buffer $(50 \mathrm{mmol} / \mathrm{l}$ Tris- $\mathrm{HCl} \mathrm{pH} 9.5,2.6 \mathrm{mmol} / \mathrm{l}$ EDTA, 
$1.4 \mathrm{mmol} / \mathrm{l} \mathrm{NAD}, 1 \mathrm{mmol} / \mathrm{l} \mathrm{ADP})$ using an LS-50B fluorimeter (Perkin-Elmer, Bucks, UK). After a 5-min equilibration period, the addition of $1 \mathrm{mmol} / \mathrm{l} \mathrm{L}$-glutamate started the reaction and 20 min later an excess of purified bovine GDH was added as control.

For immunofluorescence, cells were grown on polyornithine-treated glass coverslips for 3 days prior to infection with Ad-LacZ or Ad-GDH for $90 \mathrm{~min}$. The next day cells were loaded with $100 \mathrm{nmol} / \mathrm{l}$ mitotracker (Molecular Probes, Leiden, The Netherlands) for $25 \mathrm{~min}$ at $37^{\circ} \mathrm{C}$ to stain mitochondria. Then cells were fixed as described [40] before incubation with anti-GDH (1:1000, Rockland) and then goat anti-rabbit IgG fluorescein (1:500) antibodies (Chemicon, Temecula, Calif., USA). Cells were viewed using a Zeiss laserscan confocal 410 microscope (Carl Zeiss, Göttingen, Germany).

Measurement of amino acid levels. INS-1E cells were cultured for 2 to 3 days in six-well plates, infected with Ad-GDH or Ad-lacZ in $1 \mathrm{ml} \mathrm{RPMI-1640} \mathrm{medium} \mathrm{for} 90 \mathrm{~min}$ and assayed the next day. Prior to the experiments, cells were maintained for $2 \mathrm{~h}$ in glucose- and glutamine-free culture medium. The cells were then washed with Krebs-Ringer bicarbonate Hepes buffer $(\mathrm{KRBH})$ with the following composition (in $\mathrm{mmol} / \mathrm{l}$ ): $135 \mathrm{NaCl}, 3.6 \mathrm{KCl}, 5 \mathrm{NaHCO}_{3}, 0.5 \mathrm{NaH}_{2} \mathrm{PO}_{4}, 0.5 \mathrm{MgCl}_{2}$, $1.5 \mathrm{CaCl}_{2}, 10$ Hepes, $\mathrm{pH}$ 7.4. Next, cells were subjected to 60 min incubation in KRBH with 2.8 or $16.7 \mathrm{mmol} / \mathrm{l}$ glucose. The incubation was stopped by putting the plates on ice and washing the cells with ice cold PBS. Cells were then extracted with $35 \%$ sulfosalicylic acid for $18 \mathrm{~h}$ at $4{ }^{\circ} \mathrm{C}$ and samples were frozen at $-80^{\circ} \mathrm{C}$, before amino acid measurements were done by reverse-phase high-pressure liquid chromatography (HPLC) after derivatisation with o-phthalaldehyde [41].

Mitochondrial membrane potential and ATP generation. INS$1 \mathrm{E}$ cells were cultured 2 to 3 days, infected with Ad-GDH or Ad-lacZ for $90 \mathrm{~min}$ and used for experiments the next day. Mitochondrial membrane potential $\left(\Delta \Psi_{\mathrm{m}}\right)$ was measured as described [42] using rhodamine-123. Cells were used as a suspension in KRBH buffer and gently stirred in a fluorimeter cuvette at $37^{\circ} \mathrm{C}$. Then fluorescence was excited at $490 \mathrm{~nm}$ and measured at $530 \mathrm{~nm}$. Cytosolic ATP levels were monitored in cells expressing the ATP-sensitive bioluminescent probe luciferase after infection with the specific viral construct $[15,43]$.

Insulin secretion assay. INS-1E cells cultured in 24-well plates were infected over a 90-min period with either Ad-GDH or Ad-LacZ adenovirus and assayed the next day. Prior to the experiments, cells were maintained for 2 hours in glucose- and glutamine-free culture medium. The cells were then washed and preincubated further in glucose-free $\mathrm{KRBH}$, supplemented with $0.1 \%$ bovine serum albumin as carrier, before the incubation period $\left(30 \mathrm{~min}\right.$ at $\left.37^{\circ} \mathrm{C}\right)$ with different glucose concentrations, L-leucine or $\mathrm{KCl}$.

Isolated rat islets were infected with Ad-GDH or Ad-LacZ adenovirus over a 90-min period on the day after isolation and further cultured for $24 \mathrm{~h}$ before the secretion assay. Islet perifusions were carried out using 15 to 20 hand-picked islets per chamber of $250 \mu \mathrm{l}$ volume, thermostatted at $37^{\circ} \mathrm{C}$ (Brandel, Gaithersburg, Md., USA). The flux was set at $0.5 \mathrm{ml} / \mathrm{min}$ and fractions were collected every minute after a 20-min washing period at basal glucose. At the end of the perifusion period islets were taken out of the chamber and acid-EtOH extracts were used to measure the insulin content. Insulin levels were determined by radioimmunoassay using rat insulin as standard [13]. Insulin secretion was expressed as the fraction of insulin collected every minute over total insulin content per corresponding chamber (\% content). All compounds tested on insu- lin secretion were obtained from Sigma-Aldrich (Buchs, Switzerland). The 2-aminobicyclo-[2,2,1]heptane-2-carboxylic acid $(\mathrm{BCH})$ used was a mixture of exo- and endo-isomers.

Cellular metabolism assessed by the MTT assay. The 3-(4,5-dimethylthiazol-2-yl)-2,5,-diphenyl tetrazolium bromide (MTT) assay measures the redox potential of cells through formation of formazans precipitated from tetrazolium salts, and was used as described previously [44, 45]. Briefly, this colorimetric assay measures the reduction of MTT that enters the cells, where MTT is reduced, essentially by mitochondrial dehydrogenases. Isolated rat islets were infected with Ad-GDH or Ad-LacZ adenovirus over a 90-min period on the day after isolation and used the next day. Batches of 40 hand-picked islets were distributed into wells of 96-well plates, pre-incubated for 1 hour in $\mathrm{KRBH}$ with $2.8 \mathrm{mmol} / \mathrm{l}$ glucose, before adding the indicated stimulation conditions in $100 \mu \mathrm{l}$. After $30 \mathrm{~min}$ an aliquot of the supernatant was collected for insulin release measurement and the reaction was continued for $90 \mathrm{~min}$ in the presence of $0.5 \mathrm{mg} / \mathrm{ml}$ MTT (Sigma). Next, formazan precipitates were extracted (20\% SDS, 50\% DMF) overnight and absorbance recorded at $570 \mathrm{~nm}$.

Statistical analyses. Where applicable, the results were expressed as means \pm SD. Differences between groups were analysed by Student's $t$ test for unpaired data and significance assessed by a $p$ value of less than 0.05 .

\section{Results}

Assessment of adenovirus-mediated GDH overexpression in INS-1E cells. Immunoblotting of the prepared cells using anti-bovine GDH antibody revealed a band at the expected size of $54 \mathrm{M}_{\mathrm{r}}$, Ad-LacZ representing expression of endogenous GDH (Fig. 1a). Using Ad$\mathrm{GDH}, \mathrm{GDH}$ was overexpressed in a dose-dependent manner, i.e. 7.4-fold at $0.5 \mu \mathrm{l}, 9.7$-fold at $1.0 \mu \mathrm{l}$ and 13.9-fold at $5.0 \mu \mathrm{l}$ versus Ad-LacZ, as determined by quantitative densitometry. To test whether this overexpressed protein was functional, GDH activity was measured in cell extracts of transduced INS-1E cells. GDH activity, monitored under the oxidative deamination direction, was no different in INS-1E cells transduced with Ad-LacZ control virus than it was in noninfected cells (Fig. 1b). Infections with increasing concentrations of the Ad-GDH virus resulted in a dose-dependent increase in GDH enzymatic reaction rates. After infection with $1.0 \mu \mathrm{l} / \mathrm{ml} \mathrm{Ad}-\mathrm{GDH}$, immunofluorescence showed mitochondrial localisation of GDH (Fig. 1c,d), although some cytosolic staining was observed in control and in cells overexpressing GDH. At high Ad-GDH virus concentrations $(5.0 \mu \mathrm{l} / \mathrm{ml})$, stronger cytosolic staining was observed (not shown). Taken together, these data show that functional GDH can be efficiently overexpressed. Consequently a virus concentration of $1.0 \mu \mathrm{l} / \mathrm{ml}$ was selected for the rest of the study.

Mitochondrial membrane potential and ATP generation in INS-1E cells. In control cells transduced with Ad-LacZ virus, $\Delta \Psi_{\mathrm{m}}$ was hyperpolarised by raising 
a
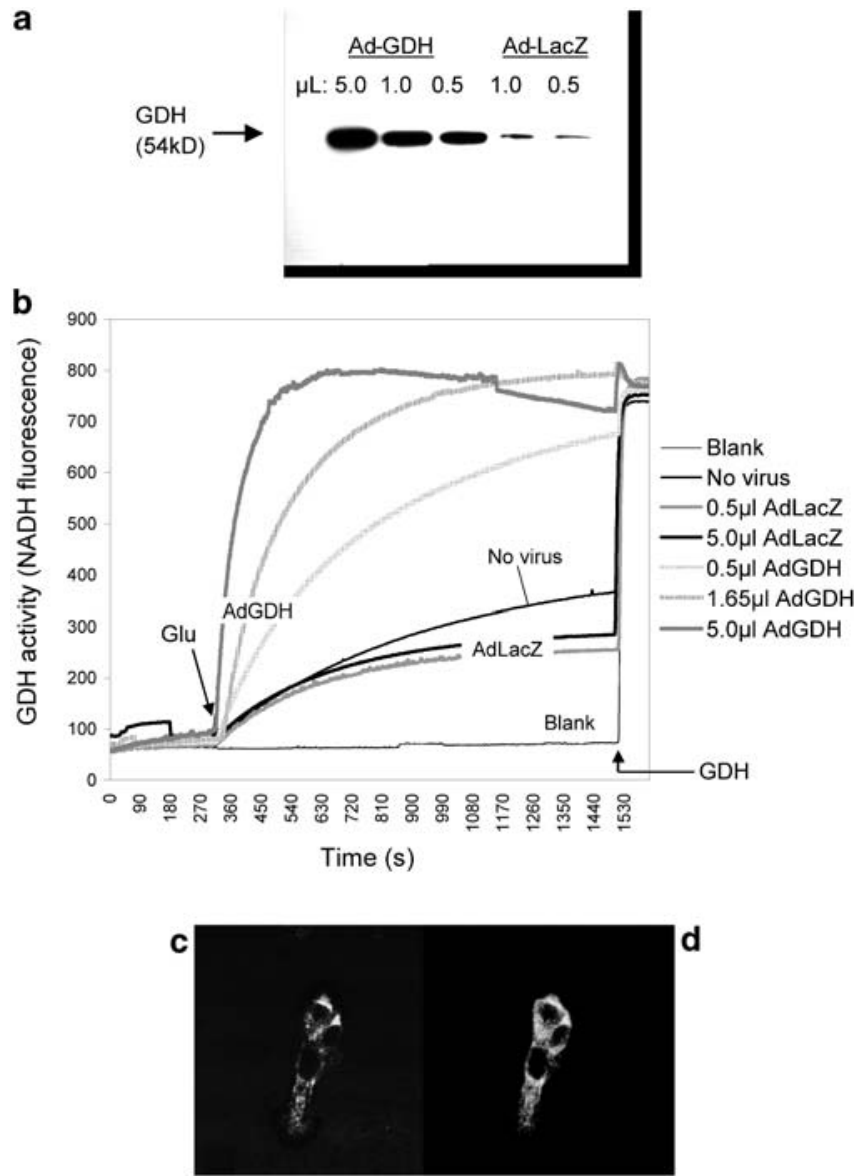

Fig. 1a-c. GDH in insulinoma INS-1E cells infected with AdLacZ and Ad-GDH purified adenoviruses. Cells were cultured in six-well plates for 4 days and infected for $90 \mathrm{~min}$ at the indicated concentrations and analysed the next day. Immunoblotting (a) using anti-GDH antibody showed a band at the expected size of $54 \mathrm{M}_{\mathrm{r}}$. On this representative immunoblot (1 of 5) glutamate dehydrogenase (GDH) was overexpressed in a dosedependent manner in Ad-GDH-infected cells. GDH activity (b) was monitored in cell extracts under the oxidative deamination direction as NADH fluorescence. The reaction was started by adding $1 \mathrm{mmol} / \mathrm{l}$ glutamate (Glu) and $20 \mathrm{~min}$ later purified bovine GDH was added as positive control. Cellular localization of GDH in the cells transduced with Ad-GDH was investigated the day after infection. Mitochondrial staining was done using the dye mitotracker (c) and GDH was revealed by immunofluorescence using anti-GDH antibody (d). Observations are representative of five to six independent experiments

glucose from basal $2.8 \mathrm{mmol} / \mathrm{l}$ to $12.8 \mathrm{mmol} / \mathrm{l}$ (Fig. 2a). Further addition of the protonophore FCCP (carbonyl cyanide p-trifluoromethoxyphenylhydrazone) resulted in a rapid depolarisation, reflecting dissipation of the proton gradient. Similar effects were seen in cells overexpressing GDH. In accordance with $\Delta \Psi_{\mathrm{m}}$, ATP generation, monitored in cells expressing luciferase, was not affected by GDH overexpression (Fig. 2b). Indeed, raising glucose from 2.8 to $12.8 \mathrm{mmol} / \mathrm{l}$ increased cytosolic ATP levels to similar extents in Ad-LacZ and Ad-GDH groups, i.e. $145 \pm 13 \%$ versus $142 \pm 9 \%$ of basal values ( $n=5$ inde- a

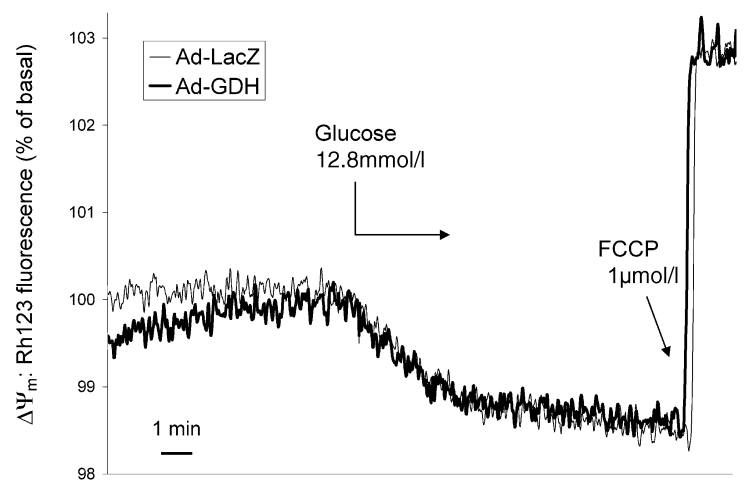

b

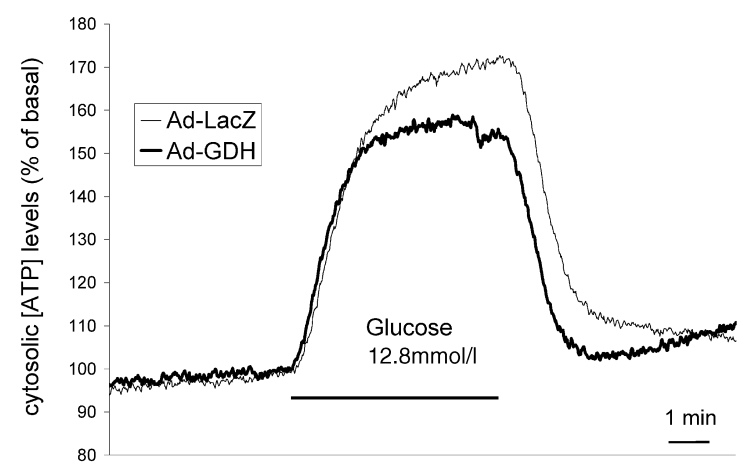

Fig. 2a, b. Mitochondrial activation in INS-1E cells overexpressing glutamate dehydrogenase $(\mathrm{GDH})$. The cells were infected for 90-min period with Ad-GDH or Ad-LacZ adenovirus and analysed the next day. Mitochondrial membrane potential $\left(\Delta \Psi_{\mathrm{m}}\right)$ was monitored (a) as rhodamine-123 fluorescence. Each trace started at $2.8 \mathrm{mmol} / \mathrm{l}$ glucose, which was raised to $12.8 \mathrm{mmol} / \mathrm{l}$ before complete depolarization induced by $1 \mu \mathrm{mol} / \mathrm{l}$ carbonyl cyanide p-trifluoromethoxyphenylhydrazone (FCCP). Cytosolic ATP levels were monitored (b) in cells expressing the ATP-sensitive bioluminescent probe luciferase. Observations are representative of three to five independent experiments. Statistics: see Results section

pendent experiments). Therefore, GDH overexpression does not modify glucose-mediated activation of the electron transport chain (judged here as $\Delta \Psi_{\mathrm{m}}$ ) or ATP generation.

Amino acid levels in INS-1E cells overexpressing $G D H$. Several amino acids were measured by HPLC in INS-1E cells transduced with corresponding viruses (Table 1). In control cells, two amino acids were increased by high glucose, i.e. alanine (4.8-fold, $p<0.01)$ and glutamate (2.8-fold, $p<0.01)$. Conversely, aspartate and $\gamma$-aminobutyric acid (GABA) were decreased under the same conditions $(-65 \%, p<0.01$ and $-23 \%, p<0.05$ respectively). In INS-1E cells overexpressing GDH only glutamate was increased (3.4-fold, $p<0.01)$ and aspartate lowered $(-69 \%, p<0.05)$ at $16.7 \mathrm{mmol} / \mathrm{l}$ glucose compared with basal $2.8 \mathrm{mmol} / \mathrm{l}$ glucose. Finally, GABA, which is a decarboxylation product of glutamate, was decreased by GDH overexpression compared with the corresponding Ad-LacZ group at $16.7 \mathrm{mmol} / \mathrm{l}$ glucose $(-31 \%, p<0.05)$. 


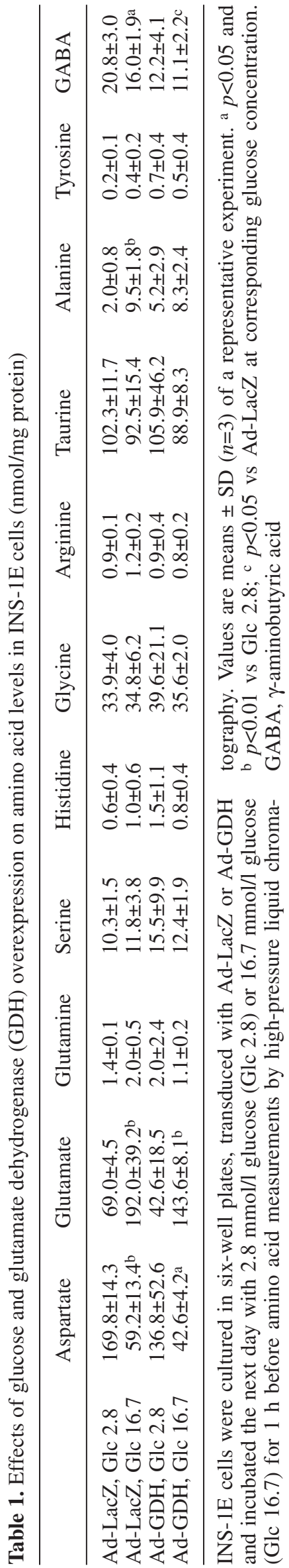

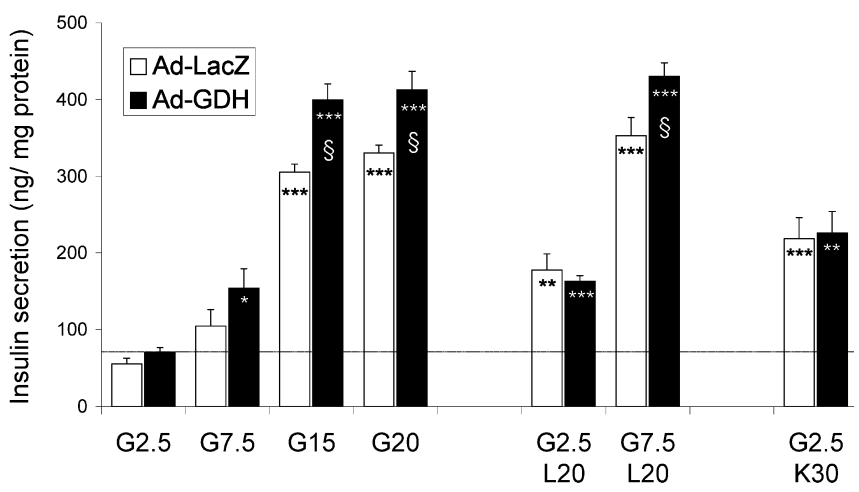

Fig. 3. Insulin secretion in INS-1E cells overexpressing glutamate dehydrogenase (GDH). The cells were infected for a 90 min with Ad-GDH or Ad-LacZ adenovirus and analysed the next day. After preincubation and rinsing in glucose-free buffer, cells were challenged for $30 \mathrm{~min}$ with: $2.5,7.5,15$ and $20 \mathrm{mmol} / \mathrm{l}$ glucose; $20 \mathrm{mmol} / \mathrm{l} \mathrm{L}$-leucine (at 2.5 or $7.5 \mathrm{mmol} / \mathrm{l}$ glucose); and $30 \mathrm{mmol} / 1 \mathrm{KCl}$ (at $2.5 \mathrm{mmol} / \mathrm{l}$ glucose). Observations are representative of 3 to 6 independent experiments. $* p<0.05, * * p<0.01$ and $* * * p<0.001$ vs basal glucose; ${ }^{\S} p<0.05$ vs Ad-LacZ at corresponding glucose concentrations

Insulin secretion in INS-1E cells overexpressing $G D H$. Prepared cells were challenged for 30 min with different glucose concentrations or with L-leucine. Insulin secretion was also stimulated at basal $2.5 \mathrm{mmol} / \mathrm{l}$ glucose with $30 \mathrm{mmol} / \mathrm{l} \mathrm{KCl}$, used as a $\mathrm{Ca}^{2+}$ raising agent as a consequence of membrane depolarisation and opening of voltage-gated $\mathrm{Ca}^{2+}$ channels (Fig. 3). In control cells (Ad-LacZ), stepwise increases of glucose from basal $2.5 \mathrm{mmol} / \mathrm{l}$ to $20 \mathrm{mmol} / \mathrm{l}$ led to a dose-dependent stimulation of insulin release (up to 5.9 -fold at $20 \mathrm{mmol} / \mathrm{l}$ glucose, $p<0.001$ vs basal). Leucine is both a mitochondrial substrate and an allosteric activator of GDH. At $2.5 \mathrm{mmol} / \mathrm{l}$ glucose, $20 \mathrm{mmol} / \mathrm{l}$ L-leucine evoked a 3.2 -fold $(p<0.005)$ secretory response, which was further increased at $7.5 \mathrm{mmol} / \mathrm{l}$ glucose $(6.3$-fold, $p<0.001$ ), indicating an additive effect of the amino acid on the sugar. Overexpression of GDH did not modify basal insulin release, whereas at 15 and $20 \mathrm{mmol} / \mathrm{l}$ glucose the secretory responses were $31 \%$ $(p<0.05)$ and $25 \%(p<0.05)$ greater respectively, compared with corresponding glucose-matched controls. The combined effects of $7.5 \mathrm{mmol} / \mathrm{l}$ glucose plus $20 \mathrm{mmol} / \mathrm{l} \mathrm{L}$-leucine were potentiated by GDH overexpression $(22 \%$ higher, $p<0.05)$. Non-nutrient induced insulin secretion, by exposure to depolarising concentrations of $\mathrm{KCl}$, resulted in similar stimulations in the Ad-LacZ and Ad-GDH groups (3.9-fold and 4.1-fold respectively). These data show that GDH overexpression in INS-1E cells specifically potentiates optimal nutrient-evoked insulin secretion.

GDH overexpression and insulin secretion in rat and mouse islets. Immunoblotting of the prepared islets (Fig. 4a) confirmed that rat islets express higher levels 
a

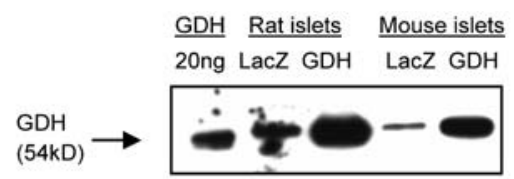

b

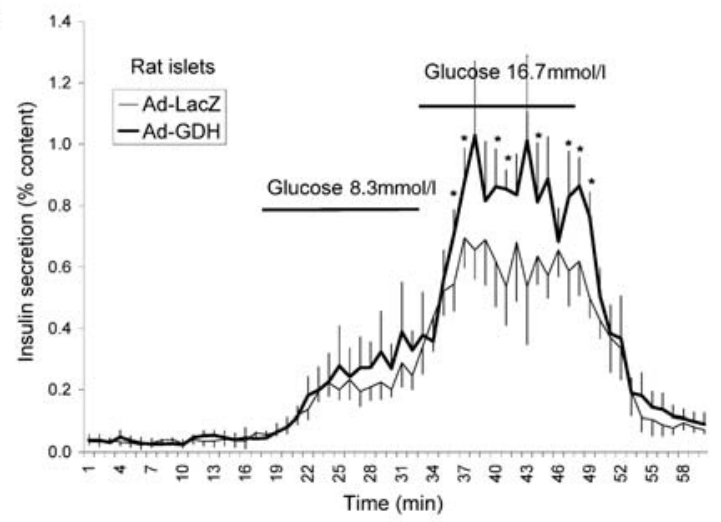

C

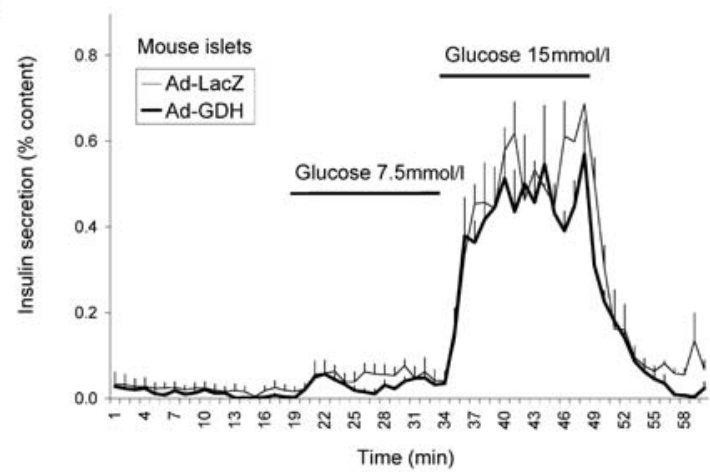

Fig. 4a, b. Effect of glutamate dehydrogenase (GDH) overexpression on glucose-stimulated insulin secretion in rat and mouse islets. Isolated rat or mouse islets were infected with Ad-GDH or Ad-LacZ adenovirus for $90 \mathrm{~min}$ on the day after isolation and further cultured for $24 \mathrm{~h}$ before secretion assay. Islet perifusions were done using 20 islets per chamber at $0.5 \mathrm{ml} / \mathrm{min}$ and fractions were collected every minute. Control of GDH overexpression by immunoblotting (a) in rat and mouse pancreatic islets. Rat islets (b): after a period at basal $2.8 \mathrm{mmol} / \mathrm{l}$ glucose, insulin secretion was stimulated by raising glucose from 2.8 to $8.3 \mathrm{mmol} / \mathrm{l}$ for $15 \mathrm{~min}$, directly followed by $15 \mathrm{~min}$ at $16.7 \mathrm{mmol} / \mathrm{l}$ glucose, then returning to $2.8 \mathrm{mmol} / \mathrm{l}$. Mouse islets (c): glucose was raised from 2.5 to $7.5 \mathrm{mmol} / \mathrm{l}$ for $15 \mathrm{~min}$ before stimulation by $15 \mathrm{mmol} / \mathrm{l}$ glucose for the next $15 \mathrm{~min}$. Values are means $\pm \mathrm{SD}$ ( $n=4$ per group) of one out of three independent experiments. Calculation of the areas under the curves and corresponding statistics are given in the Results section. ${ }^{*} p<0.05$ vs Ad-LacZ for corresponding time points

(4.1-fold) of endogenous GDH than mouse islets and showed efficient overexpression of GDH following virus infection. Controls of enhanced enzymatic activity were also done as described for INS-1E cells in Fig. 1b.

Rat islets transduced with control Ad-LacZ virus responded to glucose stimulation by a sustained increase in rate of insulin secretion at $8.3 \mathrm{mmol} / \mathrm{l}$ glucose, fur- ther enhanced at $16.7 \mathrm{mmol} / \mathrm{l}$ glucose (Fig. 4b). Overexpression of GDH had no significant effects at basal $(2.8 \mathrm{mmol} / \mathrm{l})$ or intermediate $(8.3 \mathrm{mmol} / \mathrm{l})$ glucose concentrations. In contrast, at $16.7 \mathrm{mmol} / \mathrm{l}$ glucose the secretory response was $35 \%$ greater in islets overexpressing GDH than in controls [area under the curve $(\mathrm{AUC})=11.50 \pm 1.28$ vs $8.53 \pm 0.93$ respectively (insulin release as $\%$ content), $p<0.05]$. These results are consistent with those obtained in the clonal beta-cell line INS-1E, i.e. potentiation at high but not at basal or intermediate glucose concentrations.

In mouse islets transduced with control Ad-LacZ virus we saw a right-shift of the glucose dose response compared with that of rat islets (Fig. 4c). At $7.5 \mathrm{mmol} / \mathrm{l}$ glucose there was no significant secretory response, but there was sustained sub-optimal stimulation at $15 \mathrm{mmol} / \mathrm{l}(\mathrm{AUC}=0.75 \pm 0.52$ and $6.03 \pm 1.23 \mathrm{re}-$ spectively), and strong insulin release at $25 \mathrm{mmol} / \mathrm{l}$ glucose (AUC $=8.97 \pm 0.51$ ) (see below). GDH overexpression did not modify glucose-stimulated insulin release in mouse islets.

Next, we tested the potential of optimised GDH activity in islets overexpressing GDH. Therefore, the L-leucine non-metabolisable analogue $\mathrm{BCH}$ was supplemented as an allosteric activator of GDH. At $8.3 \mathrm{mmol} / \mathrm{l}$ glucose, control rat islets responded to $10 \mathrm{mmol} / \mathrm{l} \mathrm{BCH}$ with a 2.7-fold $(p<0.001)$ rise in insulin secretion (Fig. 5a). Islets overexpressing GDH further raised their secretory response by $36 \%$ versus controls (AUC $=8.19 \pm 0.71$ vs $6.01 \pm 0.40, p<0.05$ ). Upon stepwise increases of glucose, insulin secretion profiles showed sustained monophasic kinetics (Fig. 4b). In contrast, the secretory response was biphasic when switching directly from basal 2.8 to high $16.7 \mathrm{mmol} / \mathrm{l}$ glucose (Fig. 5b). Interestingly in these conditions, the potentiating effect of GDH overexpression was specific for the second phase (AUC: $+54 \%$, $p<0.05$ vs Ad-LacZ). In Ad-GDH islets, addition of $\mathrm{BCH}$ at $16.7 \mathrm{mmol} / \mathrm{l}$ glucose did not further modify the prominent rate of insulin release, which in that case was also reached by control Ad-LacZ islets (AUC $=7.54 \pm 0.51$ vs $6.77 \pm 0.33$ respectively, $p<0.05$ ). The insulin content of islets collected from the perifusion chambers at the end of the experiment was similar in Ad-LacZ and Ad-GDH groups $(21.7 \pm 2.8$ vs $20.0 \pm 2.3 \mathrm{ng} /$ islet respectively).

In mouse islets, the addition of $10 \mathrm{mmol} / \mathrm{l} \mathrm{BCH}$ at $25 \mathrm{mmol} / \mathrm{l}$ glucose (Fig. 6a) further raised insulin secretion by $39 \%(p<0.05)$. The latter condition was potentiated by $43 \%$ in islets overexpressing GDH compared with the Ad-LacZ group (AUC $=17.9 \pm 2.6$ vs $12.5 \pm 2.0$ respectively, $p<0.05)$. Islet insulin contents at the end of the experiment were similar in the AdLacZ and Ad-GDH groups ( $23.7 \pm 4.8$ vs $28.8 \pm 16.9 \mathrm{ng} /$ islet respectively).

GDH overexpression and glutamine-induced insulin secretion. Glutamine alone does not trigger insulin re- 
a

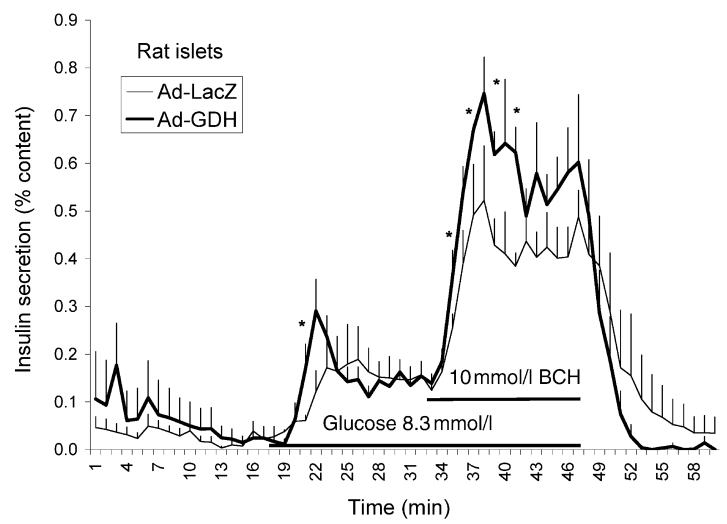

b

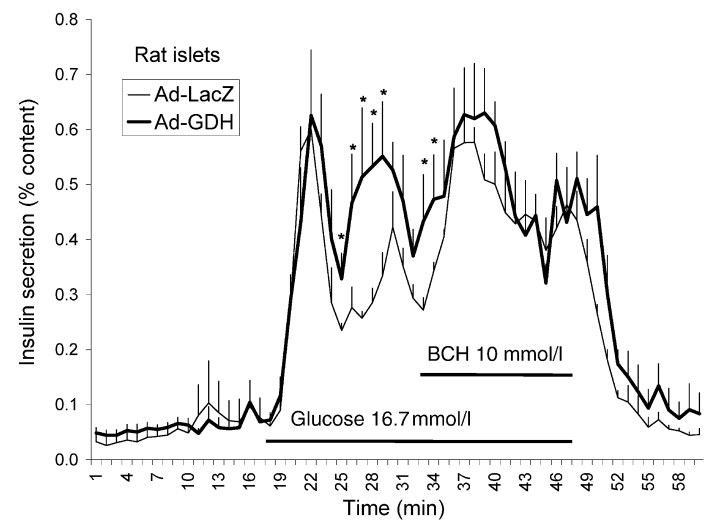

Fig. 5a, b. Effect of (+/-)-2-aminobicyclo-[2,2,1]heptane-2carboxylic acid $(\mathrm{BCH})$ on glucose-stimulated rat islets overexpressing glutamate dehydrogenase (GDH). Isolated rat islets were infected with Ad-GDH or Ad-LacZ adenovirus the day after isolation and used the next day. Islets (a) were first stimulated with $8.3 \mathrm{mmol} / \mathrm{l}$ glucose for $15 \mathrm{~min}$ before adding $10 \mathrm{mmol} / \mathrm{l} \mathrm{BCH}$ for another $15 \mathrm{~min}$. After 15 min exposure at $16.7 \mathrm{mmol} / \mathrm{l}$ glucose $(\mathbf{b}), 10 \mathrm{mmol} / \mathrm{l} \mathrm{BCH}$ were added for the next $15 \mathrm{~min}$. Values are means $\pm \mathrm{SD}$ ( $n=4$ per group) of one out of three independent experiments. For calculation of the areas under the curves and corresponding statistics, see Results section. ${ }^{*} p<0.05$ vs Ad-LacZ for corresponding time points

lease, unless specific conditions are applied such as addition of $\mathrm{BCH}$ as an activator of GDH. Accordingly, at basal glucose (Fig. 6b), control mouse islets did not respond to $5 \mathrm{mmol} / \mathrm{l}$ glutamine before adding $10 \mathrm{mmol} / \mathrm{l} \mathrm{BCH}$, which then resulted in a 14.5-fold increase of insulin release $(\mathrm{AUC}=1.1 \pm 1.5$ vs $16.6 \pm 0.2$ respectively, $p<0.005$ ). Similarly, rat islets (Fig. 7a) responded to glutamine only in the presence of $\mathrm{BCH}$, although the stimulation was weaker than in mouse islets $(2.5$-fold, $p<0.05)$. When $\mathrm{BCH}$ was added before glutamine exposure, it triggered transient insulin secretion (2.3-fold, $p<0.005$ ) (Fig. $7 \mathrm{~b}$ ), possibly due to an endogenous pool of glutamine and/or glutamate in rat islets sufficient to stimulate secretion. Rat islets transduced with Ad-GDH were made responsive to glutamine, showing a 2.7-fold increase in insulin release compared with Ad-LacZ islets $(\mathrm{AUC}=4.50 \pm 0.59$ vs $1.69 \pm 0.50$ respectively, $p<0.05$ ) (Fig. 7a). Further

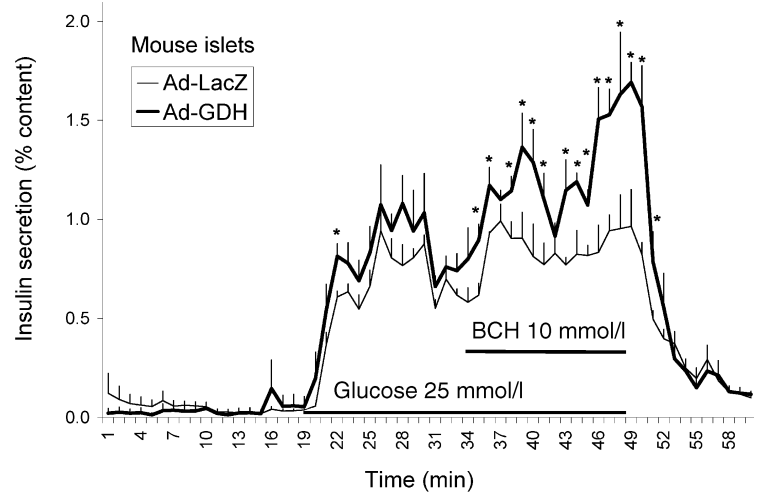

b

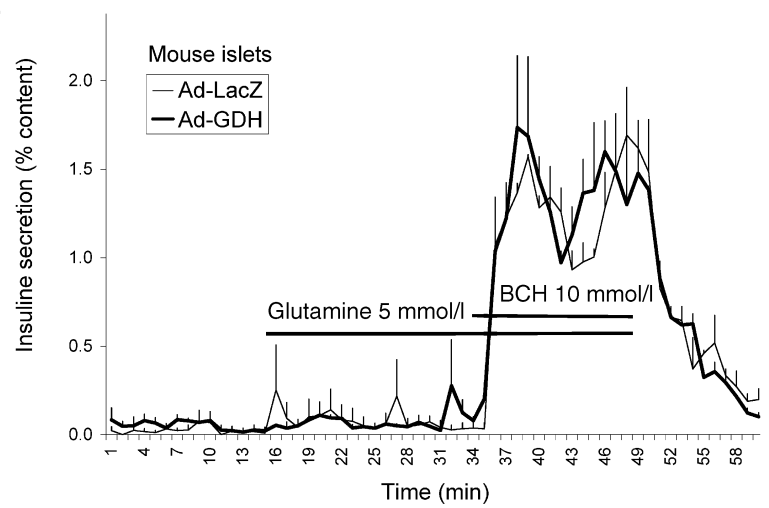

Fig. 6a, b. Effect of glutamate dehydrogenase (GDH) overexpression and activation on insulin secretion in mouse islets. Isolated mouse islets were infected with Ad-GDH or Ad-LacZ adenovirus for $90 \mathrm{~min}$ on the day after isolation and further cultured for $24 \mathrm{~h}$ before secretion assay. After a period (a) at basal $2.5 \mathrm{mmol} / \mathrm{l}$ glucose, insulin secretion was stimulated by raising glucose to $25 \mathrm{mmol} / \mathrm{l}$ for $15 \mathrm{~min}$, followed by $15 \mathrm{~min}$ with glucose $(25 \mathrm{mmol} / \mathrm{l})$ and $10 \mathrm{mmol} / \mathrm{l}(+/-)$-2-aminobicyclo-[2,2,1] heptane-2-carboxylic acid $(\mathrm{BCH})$, then returning to $2.5 \mathrm{mmol} / \mathrm{l}$ glucose. After a 15 -min exposure (b) to $5 \mathrm{mmol} / \mathrm{l}$ glutamine, $10 \mathrm{mmol} / \mathrm{l} \mathrm{BCH}$ was added for the next $15 \mathrm{~min}$. Values are means $\pm \mathrm{SD}$ ( $n=4$ per group) of one out of three independent experiments. For calculation of the areas under the curves and corresponding statistics, see Results section. $* p<0.05$ vs Ad-LacZ for corresponding time points

supplementation with $\mathrm{BCH}$ increased the secretory response in islets overexpressing GDH in comparison with controls $(2.2$-fold, $p<0.05)$. Similar results were obtained when the sequence of additions was reversed (first $\mathrm{BCH}$, then glutamine; Fig. 7b), with a 3.5-fold potentiation of insulin release associated with GDH overexpression compared to controls $(p<0.05)$. In mouse islets, GDH overexpression did not change the secretory responses to glutamine with or without $\mathrm{BCH}$ (Fig. 6b).

Glutamine can be turned into a secretagogue by $\mathrm{BCH}$ through enhanced glutamine oxidation. In the MTT assay, used to measure islet cell metabolism associated with glutamine exposure (Fig. 8a), we found that $5 \mathrm{mmol} / \mathrm{l}$ glutamine failed to promote cell metab- 

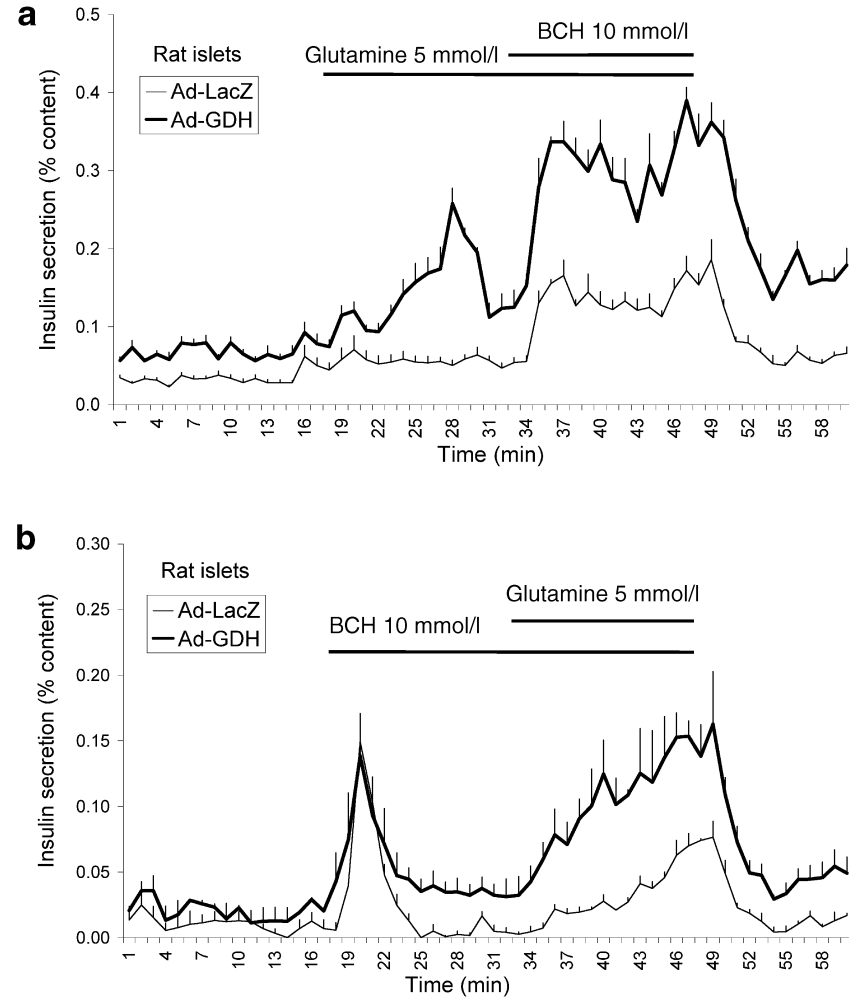

Fig. 7a, b. Effect of glutamate dehydrogenase (GDH) overexpression on glutamine-stimulated insulin secretion in rat islets. Isolated rat islets were infected with Ad-GDH or Ad-LacZ adenovirus and further cultured for $24 \mathrm{~h}$ before secretion assay. Islets (a), perifused with basal $2.8 \mathrm{mmol} / 1$ glucose, were exposed to $5 \mathrm{mmol} / \mathrm{l}$ glutamine for $15 \mathrm{~min}$ before adding $10 \mathrm{mmol} / 1$ (+/-)-2-aminobicyclo-[2,2,1] heptane-2-carboxylic acid $(\mathrm{BCH})$ for another $15 \mathrm{~min}$. Islets $(\mathbf{b})$ were first exposed to $10 \mathrm{mmol} / \mathrm{l} \mathrm{BCH}$ prior to supplementation with $5 \mathrm{mmol} / \mathrm{l}$ glutamine for $15 \mathrm{~min}$. Values are means $\pm \mathrm{SD}$ ( $n=4$ per group) of one out of three independent experiments. Statistics, see Results section

olism in control rat islets, unless $10 \mathrm{mmol} / \mathrm{l} \mathrm{BCH}$ were added ( $42 \%$ increase, $p<0.05$ vs basal $2.8 \mathrm{mmol} / 1 \mathrm{glu}$ cose conditions). In contrast, glutamine alone induced cell metabolism in islets overexpressing GDH $(62 \%$ higher, $p<0.01$ vs control islets), and this was further enhanced by adding $\mathrm{BCH}$. All these metabolic events correlated with insulin secretion (Fig. 8b). Therefore, modulations of GDH expression and/or activity determine glutamine metabolism and associated secretory responses.

\section{Discussion}

In our study GDH was overexpressed in the beta cell line INS-1E as well as in rat and mouse pancreatic islets. Pancreatic beta cells have remarkably high anaplerotic activity $[46,47]$ as a likely compensatory mechanism for important cataplerosis, i.e. leak out of a

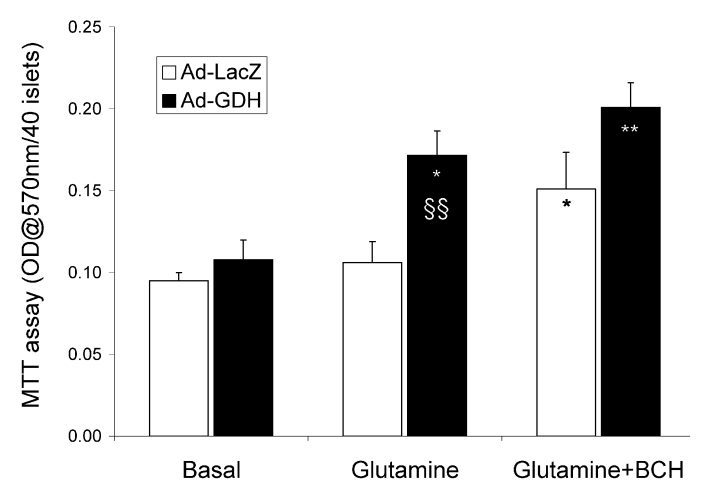

b

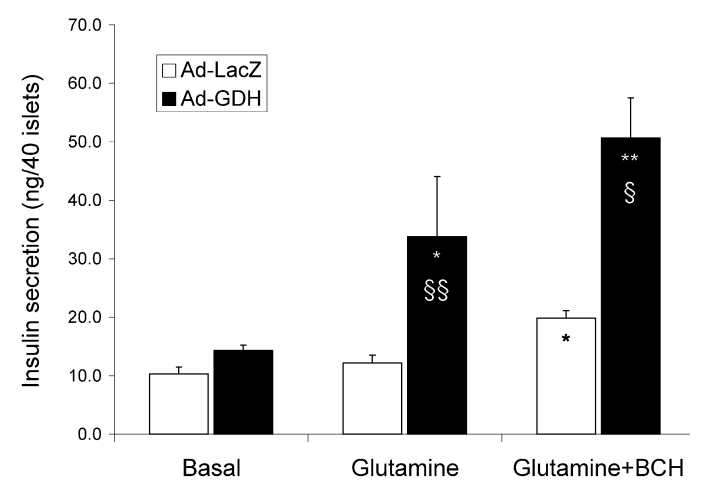

Fig. 8a, b. Effect of glutamate dehydrogenase (GDH) overexpression on glutamine-associated metabolism and insulin secretion in rat islets. Isolated rat islets were infected with AdGDH or Ad-LacZ adenovirus and further cultured for $24 \mathrm{~h}$ before distribution in 96-well plates for combined 3-(4,5-dimethylthiazol-2-yl)-2,5,-diphenyl tetrazolium bromide (MTT) assay and secretion assay. Cellular metabolism (a) was measured by MTT assay for a 90-min incubation period in basal conditions ( $2.8 \mathrm{mmol} / \mathrm{l}$ glucose), in the presence of $5 \mathrm{mmol} / \mathrm{l}$ glutamine, and with glutamine plus $10 \mathrm{mmol} / \mathrm{l}(+/-)$-2-aminobicyclo$[2,2,1]$ heptane-2-carboxylic acid (BCH). Insulin secretion (b) was measured in the supernatant of islets before the MTT assay. Values are means $\pm \mathrm{SD}$ of five independent experiments. $* p<0.05$ and ${ }^{* *} p<0.01$ vs basal $(2.8 \mathrm{mmol} / \mathrm{l}$ glucose $) ; \S p<0.05$, $\$ \$ p<0.01$ vs Ad-LacZ at corresponding conditions

the TCA cycle. GDH is one of the major cataplerotic enzymes [48] and can form glutamate from the TCA cycle intermediate, $\alpha$-ketoglutarate. Downstream of mitochondrial activation, glutamate might play a role in exocytosis, together with permissive cytosolic $\mathrm{Ca}^{2+}$ levels, by acting on secretory granules [13, 17, 49, 50]. Principally, GDH is also considered important for its anaplerotic function, mediating deamination of glutamate to $\alpha$-ketoglutarate [51]. Therefore, in pancreatic beta cells, the preferred directional flux of the enzyme is still under discussion [16, 29, 30, 31, 52], depending both on stimulation conditions and allosteric regulation.

Adenovirus-mediated overexpression of GDH potentiated the secretory responses evoked by high glucose without any effects at low glucose. This is consistent with a previous study, which was done with 
INS-1E cells by transient transfection of GDH cDNA and showed enhanced secretory responses to high glucose, measured as the release of human growth hormone, which is used as a reporter of efficiently transfected cells [53]. In that study, the combination of GDH overexpression with intermediate glucose concentrations and allosteric activation of GDH resulted in major rates of insulin release. At high glucose concentrations, GDH overexpression was also associated with potentiation of the secretory response in INS-1E cells and rat islets. In mouse islets, such potentiation was restricted to the combined effects of high glucose plus $\mathrm{BCH}$ (an activator of GDH). As basal GDH expression levels are lower in mouse than in rat islets [39], our unexpected results suggest that there is a species specificity in GDH-related metabolism. Interestingly, the effects of GDH overexpression were specific for the second phase of the secretory response, indicating that GDH exerts its principal effect in the sustained phase of insulin release. These results show that normal GDH expression levels in islets are sufficient for intermediate glucose-evoked insulin release, but are rate-limiting for optimal secretory responses to high glucose.

Unlike glucose, glutamine poorly stimulates mitochondrial metabolism under normal conditions and as a result, ATP production is only weak in islets with such a stimulus [24, 25, 54]. Consequently, ATP generation is probably not sufficient to depolarise the plasma membrane through closure of ATP-sensitive $\mathrm{K}^{+}$channels, a process which is required for cytosolic $\mathrm{Ca}^{2+}$ increase. Therefore, islet glutamate levels can be markedly increased by exposure to extracellular glutamine and, because of scarce conversion of glutamate to $\alpha$-ketoglutarate [24], without stimulation of insulin secretion $[24,55]$. Activation of GDH by L-leucine or its non-metabolisable analogue $\mathrm{BCH}$ increases glutamine oxidation and insulin secretion, essentially by enhancing the oxidative deamination of glutamate $[25$, $27,28,29,32,33,56]$. GDH activity is under the tight control of allosteric effectors, although the flux direction depends chiefly on the relative supply of substrates and cofactors, i.e. glutamate, $\alpha$-ketoglutarate, and $\mathrm{NAD}(\mathrm{P})^{+} / \mathrm{H}$ respectively. Accordingly, glutamine oxidation stimulated by the presence of an allosteric activator of GDH is inhibited by glucose [28], which increases the carbon pool on the TCA cycle side. The glutamate and $\alpha$-ke toglutarate pathway is operated either by GDH or alternatively by transamination reactions $[57,58]$. In the latter case, aspartate conversion to oxaloacetate serves as the ammonium donor for $\alpha$ ketoglutarate, resulting in the formation of glutamate. From the present data, one cannot precisely assess the relative contributions of GDH and transamination reactions. However, upon glucose stimulation in INS-1E cells, increased glutamate was associated with a decrease in aspartate. Moreover, GDH overexpression did not modify the glucose-induced increase in cellu- lar glutamate concentrations. It has been shown by NMR spectroscopy in beta-cell lines that glutamate is a major product of glucose metabolism [31, 59]. Taken together, these results indicate a prominent contribution of transamination reactions in the generation of glutamate under glucose stimulation, in accordance with a recent report [60].

After glutamine exposure, the glutamate thus formed is increased but poorly converted to TCA cycle intermediates unless $\mathrm{BCH}$ (or L-leucine) allosterically activates GDH, thereby promoting mitochondrial activation and ATP generation. Such effects were observed in the present study when glutamine enhanced cellular metabolism in rat islets exposed to $\mathrm{BCH}$, correlating with stimulation of insulin secretion. Remarkably, overexpression of GDH was sufficient to turn glutamine into an effective secretagogue together with metabolism induction. Combined GDH overexpression with its activation by $\mathrm{BCH}$ further potentiated the secretory responses evoked by glutamine. Thus, it is shown here that tight control of insulin secretion can be altered when the activity of the key enzyme GDH is modified with profound alterations of secretory responses. Expression of mutant GDH, which is associated with unregulated increased GDH activity and hyperinsulinism syndrome [8], has been recently examined in a beta-cell line [61]. Expression of the activating mutation was associated with glutamine-evoked insulin secretion, whereas glucose dose response was left-shifted [61]. Together these data show that in beta cells, under physiological conditions, GDH prevents the potential secretagogue function of glutamine and could be rate limiting for that of glucose. The lack of secretory response to glutamine could result from defective ATP generation.

Glutamine is the most abundant amino acid in muscle and plasma [62]. Accordingly, muscle is an important reservoir from which the glutamine pool can be mobilised during acute exercise [63]. Moreover, following an overnight fast, there is a net release of amino acids from skeletal muscle, glutamine being quantitatively most prominent [48]. Acute exercise as well as an overnight fast are both physiological states in which insulin secretion must be avoided. This is consistent with the low expression of monocarboxylate transporter in beta cells, which avoids pyruvate and lactate-induced insulin release [64]. Clinical significance of such undesired secretory responses has recently been reported in the form of an autosomal trait characterised by abnormal pyruvate-induced insulin release and exercise-induced hyperinsulinaemic hypoglycaemia [65]. We conclude that GDH could play a key role in beta cells as a gatekeeper to prevent amino acids, in particular glutamine, from being effective secretagogues. 
Acknowledgements. We are indebted to G. Chaffard for expert technical assistance as well as to C.B. Wollheim and J. Tamarit-Rodriguez for stimulating discussions. We thank C.A. Stanley and B.Y. Hsu (The Children's Hospital of Philadelphia, Philadelphia, Pa., USA) for providing $h G L U D 1$ cDNA. The work was supported by grants to P. Maechler from the Swiss National Science Foundation (No. 31-67023.01), the European Foundation for the Study of Diabetes/Johnson \& Johnson, and Dr. Max Cloetta Foundation (Zurich, Switzerland). This study was part of the Geneva Programme for Metabolic Disorders

\section{References}

1. Michaelidis TM, Tzimagiorgis G, Moschonas NK, Papamatheakis J (1993) The human glutamate dehydrogenase gene family: gene organization and structural characterization. Genomics 16:150-160

2. Hudson RC, Daniel RM (1993) L-glutamate dehydrogenases: distribution, properties and mechanism. Comp Biochem Physiol B 106:767-792

3. Anderson CM, Swanson RA (2000) Astrocyte glutamate transport: review of properties, regulation, and physiological functions. Glia 32:1-14

4. Nissim I (1999) Newer aspects of glutamine/glutamate metabolism: the role of acute $\mathrm{pH}$ changes. Am J Physiol 277: F493-F497

5. Sener A, Malaisse WJ (1980) L-leucine and a nonmetabolized analogue activate pancreatic islet glutamate dehydrogenase. Nature 288:187-189

6. Bryla J, Michalik M, Nelson J, Erecinska M (1994) Regulation of the glutamate dehydrogenase activity in rat islets of Langerhans and its consequence on insulin release. Metabolism 43:1187-1195

7. Yang SJ, Huh JW, Kim MJ et al. (2003) Regulatory effects of 5'-deoxypyridoxal on glutamate dehydrogenase activity and insulin secretion in pancreatic islets. Biochimie 85:581-586

8. Stanley CA, Lieu YK, Hsu BY et al. (1998) Hyperinsulinism and hyperammonemia in infants with regulatory mutations of the glutamate dehydrogenase gene. N Engl J Med 338:1352-1357

9. Yorifuji T, Muroi J, Uematsu A, Hiramatsu H, Momoi T (1999) Hyperinsulinism-hyperammonemia syndrome caused by mutant glutamate dehydrogenase accompanied by novel enzyme kinetics. Hum Genet 104:476-479

10. Fisher HF (1985) L-Glutamate dehydrogenase from bovine liver. Methods Enzymol 113:16-27

11. Smith TJ, Peterson PE, Schmidt T, Fang J, Stanley CA (2001) Structures of bovine glutamate dehydrogenase complexes elucidate the mechanism of purine regulation. J Mol Biol 307:707-720

12. Stanley CA, Fang J, Kutyna K et al. (2000) Molecular basis and characterization of the hyperinsulinism/hyperammonemia syndrome: predominance of mutations in exons 11 and 12 of the glutamate dehydrogenase gene. HI/HA Contributing Investigators. Diabetes 49:667-673

13. Maechler P, Wollheim CB (1999) Mitochondrial glutamate acts as a messenger in glucose-induced insulin exocytosis. Nature 402:685-689

14. MacDonald MJ, Fahien LA (2000) Glutamate is not a messenger in insulin secretion. J Biol Chem 275:3402534027

15. Rubi B, Ishihara H, Hegardt FG, Wollheim CB, Maechler $P$ (2001) GAD65-mediated glutamate decarboxylation reduces glucose-stimulated insulin secretion in pancreatic beta cells. J Biol Chem 276:36391-36396
16. Bertrand G, Ishiyama N, Nenquin M, Ravier MA, Henquin JC (2002) The elevation of glutamate content and the amplification of insulin secretion in glucose-stimulated pancreatic islets are not causally related. J Biol Chem 277:32883-32891

17. Hoy M, Maechler P, Efanov AM, Wollheim CB, Berggren PO, Gromada J (2002) Increase in cellular glutamate levels stimulates exocytosis in pancreatic beta-cells. FEBS Lett 531:199-203

18. Liu YJ, Cheng H, Drought H, MacDonald MJ, Sharp GW, Straub SG (2003) Activation of the KATP channel-independent signaling pathway by the nonhydrolyzable analog of leucine, BCH. Am J Physiol Endocrinol Metab 285: E380-E389

19. Henquin JC (2000) Triggering and amplifying pathways of regulation of insulin secretion by glucose. Diabetes 49 : $1751-1760$

20. Maechler P, Wollheim CB (2001) Mitochondrial function in normal and diabetic beta-cells. Nature 414:807-812

21. Miki T, Nagashima K, Seino S (1999) The structure and function of the ATP-sensitive $\mathrm{K}+$ channel in insulin-secreting pancreatic beta-cells. J Mol Endocrinol 22:113-123

22. Rorsman P (1997) The pancreatic beta-cell as a fuel sensor: an electrophysiologist's viewpoint. Diabetologia 40:487-495

23. Lang J (1999) Molecular mechanisms and regulation of insulin exocytosis as a paradigm of endocrine secretion. Eur J Biochem 259:3-17

24. Malaisse WJ, Sener A, Carpinelli AR et al. (1980) The stimulus-secretion coupling of glucose-induced insulin release. XLVI. Physiological role of L-glutamine as a fuel for pancreatic islets. Mol Cell Endocrinol 20:171-189

25. Panten U, Zielmann S, Langer J, Zunkler BJ, Lenzen S (1984) Regulation of insulin secretion by energy metabolism in pancreatic B-cell mitochondria. Studies with a nonmetabolizable leucine analogue. Biochem J 219:189-196

26. Heimberg H, De Vos A, Vandercammen A, Schaftingen E van, Pipeleers D, Schuit F (1993) Heterogeneity in glucose sensitivity among pancreatic beta-cells is correlated to differences in glucose phosphorylation rather than glucose transport. EMBO J 12:2873-2879

27. Sener A, Malaisse-Lagae F, Malaisse WJ (1981) Stimulation of pancreatic islet metabolism and insulin release by a nonmetabolizable amino acid. Proc Natl Acad Sci USA 78: 5460-5464

28. Gao ZY, Li G, Najafi H, Wolf BA, Matschinsky FM (1999) Glucose regulation of glutaminolysis and its role in insulin secretion. Diabetes 48:1535-1542

29. Li C, Najafi H, Daikhin Y et al. (2003) Regulation of leucine-stimulated insulin secretion and glutamine metabolism in isolated rat islets. J Biol Chem 278:2853-2858

30. Maechler P (2002) Mitochondria as the conductor of metabolic signals for insulin exocytosis in pancreatic beta-cells. Cell Mol Life Sci 59:1803-1818

31. Broca C, Brennan L, Petit P, Newsholme P, Maechler P (2003) Mitochondria-derived glutamate at the interplay between branched-chain amino acid and glucose-induced insulin secretion. FEBS Lett 545:167-172

32. Fahien LA, MacDonald MJ, Kmiotek EH, Mertz RJ, Fahien CM (1988) Regulation of insulin release by factors that also modify glutamate dehydrogenase. J Biol Chem 263:13610-13614

33. Malaisse-Lagae F, Sener A, Garcia-Morales P, Valverde I, Malaisse WJ (1982) The stimulus-secretion coupling of amino acid-induced insulin release. Influence of a nonmetabolized analog of leucine on the metabolism of glutamine in pancreatic islets. J Biol Chem 257:3754-3758

34. Merglen A, Theander S, Rubi B, Chaffard G, Wollheim CB, Maechler P (2003) Glucose sensitivity and metabolism-se- 
cretion coupling studied during two-year continuous culture in INS-1E insulinoma cells. Endocrinology (in press)

35. Asfari M, Janjic D, Meda P, Li G, Halban PA, Wollheim CB (1992) Establishment of 2-mercaptoethanol-dependent differentiated insulin-secreting cell lines. Endocrinology 130:167-178

36. Pralong WF, Spat A, Wollheim CB (1994) Dynamic pacing of cell metabolism by intracellular $\mathrm{Ca} 2+$ transients. J Biol Chem 269:27310-27314

37. Niwa H, Yamamura K, Miyazaki J (1991) Efficient selection for high-expression transfectants with a novel eukaryotic vector. Gene 108:193-199

38. Miyake S, Makimura M, Kanegae Y (1996) Efficient generation of recombinant adenoviruses using adenovirus DNA-terminal protein complex and a cosmid bearing the full-length virus genome. Proc Natl Acad Sci USA 93: $1320-1324$

39. Maechler P, Gjinovci A, Wollheim CB (2002) Implication of glutamate in the kinetics of insulin secretion in rat and mouse perfused pancreas. Diabetes 51 [Suppl 1]:S99-S102

40. Maechler P, Jornot L, Wollheim CB (1999) Hydrogen peroxide alters mitochondrial activation and insulin secretion in pancreatic beta cells. J Biol Chem 274:27905-27913

41. Bustamante J, Lobo MV, Alonso FJ et al. (2001) An osmotic-sensitive taurine pool is localized in rat pancreatic islet cells containing glucagon and somatostatin. Am J Physiol Endocrinol Metab 281:E1275-E1285

42. Maechler P, Kennedy ED, Pozzan T, Wollheim CB (1997) Mitochondrial activation directly triggers the exocytosis of insulin in permeabilized pancreatic beta-cells. EMBO J 16:3833-3841

43. Maechler P, Wang H, Wollheim CB (1998) Continuous monitoring of ATP levels in living insulin secreting cells expressing cytosolic firefly luciferase. FEBS Lett 422: 328-332

44. Mosmann T (1983) Rapid colorimetric assay for cellular growth and survival: application to proliferation and cytotoxicity assays. J Immunol Methods 65:55-63

45. Janjic D, Wollheim CB (1992) Islet cell metabolism is reflected by the MTT (tetrazolium) colorimetric assay. Diabetologia 35:482-485

46. Schuit F, De Vos A, Farfari S et al. (1997) Metabolic fate of glucose in purified islet cells. Glucose-regulated anaplerosis in beta cells. J Biol Chem 272:18572-18579

47. Lu D, Mulder H, Zhao P et al. (2002) 13C NMR isotopomer analysis reveals a connection between pyruvate cycling and glucose-stimulated insulin secretion (GSIS). Proc Natl Acad Sci USA 99:2708-2713

48. Owen OE, Kalhan SC, Hanson RW (2002) The key role of anaplerosis and cataplerosis for citric acid cycle function. J Biol Chem 277:30409-30412

49. Bai L, Zhang X, Ghishan FK (2003) Characterization of vesicular glutamate transporter in pancreatic alpha- and beta-cells and its regulation by glucose. Am J Physiol Gastrointest Liver Physiol 284:G808-G814

50. Eto K, Yamashita T, Hirose K et al. (2003) Glucose metabolism and glutamate analog acutely alkalinize $\mathrm{pH}$ of insulin secretory vesicles of pancreatic beta-cells. Am J Physiol Endocrinol Metab 285:E262-E271
51. Lenzen S, Schmidt W, Rustenbeck I, Panten U (1986) 2-ketoglutarate generation in pancreatic B-cell mitochondria regulates insulin secretory action of amino acids and 2-keto acids. Biosci Rep 6:163-169

52. Kelly A, Li C, Gao Z, Stanley CA, Matschinsky FM (2002) Glutaminolysis and insulin secretion: from bedside to bench and back. Diabetes 51 [Suppl 3]:S421-S426

53. Maechler P, Antinozzi PA, Wollheim CB (2000) Modulation of glutamate generation in mitochondria affects hormone secretion in INS-1E beta cells. IUBMB Life 50:27-31

54. Sener A, Conget I, Rasschaert J et al. (1994) Insulinotropic action of glutamic acid dimethyl ester. Am J Physiol 267: E573-E584

55. Michalik M, Nelson J, Erecinska M (1992) Glutamate production in islets of Langerhans: properties of phosphate-activated glutaminase. Metabolism 41:1319-1326

56. Malaisse WJ, Sener A, Malaisse-Lagae F et al. (1982) The stimulus-secretion coupling of amino acid-induced insulin release. Metabolic response of pancreatic islets of L-glutamine and L-leucine. J Biol Chem 257:8731-8737

57. Lenzen S, Rustenbeck I, Panten U (1984) Transamination of 3-phenylpyruvate in pancreatic B-cell mitochondria. J Biol Chem 259:2043-2046

58. Lenzen S, Schmidt W, Panten U (1985) Transamination of neutral amino acids and 2-keto acids in pancreatic B-cell mitochondria. J Biol Chem 260:12629-12634

59. Brennan L, Shine A, Hewage C et al. (2002) A nuclear magnetic resonance-based demonstration of substantial oxidative L-alanine metabolism and L-alanine-enhanced glucose metabolism in a clonal pancreatic beta-cell line: metabolism of L-alanine is important to the regulation of insulin secretion. Diabetes 51:1714-1721

60. Brennan L, Corless M, Hewage C et al. (2003) 13C NMR analysis reveals a link between L-glutamine metabolism, Dglucose metabolism and gamma-glutamyl cycle activity in a clonal pancreatic beta-cell line. Diabetologia 46:1512-1521

61. Tanizawa Y, Nakai K, Sasaki T et al. (2002) Unregulated elevation of glutamate dehydrogenase activity induces glutamine-stimulated insulin secretion: identification and characterization of a GLUD1 gene mutation and insulin secretion studies with MIN6 cells overexpressing the mutant glutamate dehydrogenase. Diabetes 51:712-717

62. Boelens PG, Nijveldt RJ, Houdijk AP, Meijer S, Leeuwen PA van (2001) Glutamine alimentation in catabolic state. J Nutr 131 [Suppl]:2569S-2577S

63. Henriksson J (1991) Effect of exercise on amino acid concentrations in skeletal muscle and plasma. J Exp Biol 160: 149-165

64. Ishihara H, Wang H, Drewes LR, Wollheim CB (1999) Overexpression of monocarboxylate transporter and lactate dehydrogenase alters insulin secretory responses to pyruvate and lactate in beta cells. J Clin Invest 104:1621-1629

65. Otonkoski T, Kaminen N, Ustinov J, Lapatto R, Meissner T, Mayatepek E, Kere J, Sipila I (2003) Physical exerciseinduced hyperinsulinemic hypoglycemia is an autosomaldominant trait characterized by abnormal pyruvate-induced insulin release. Diabetes 52:199-204 